\title{
Publisher Correction: Contextual determinants of TGF $\beta$ action in development, immunity and cancer
}

\author{
Charles J. David and Joan Massagué
}

Nature Reviews Molecular Cell Biology https://doi.org/10.1038/s41580-018-0007-0 (2018)

Published online 11 April 2018

In the section 'Combinatorial ligand perception' of the original article, DMP1 was incorrectly used in place of BMP. This has now been corrected in the HTML and PDF versions of the article.

https://doi.org/10.1038/s41580-018-0018-x I Published online 8 May 2018

\section{Publisher Correction: The cytoplasmic dynein transport machinery and its many cargoes}

Samara L. Reck-Peterson, William B. Redwine, Ronald D. Vale and Andrew P. Carter

Nature Reviews Molecular Cell Biology https://doi.org/10.1038/s41580-018-0004-3 (2018) Published online 16 April 2018

In Figure 1c of the original article, ARP1 was incorrectly labelled as ARP11. The highlight for reference 37 was mistakenly placed under reference 36 and the highlight for reference 29 should have also referred to reference 16 (instead of 19). The HTML and PDF versions of the article have now been corrected.

https://doi.org/10.1038/s41580-018-0021-2 I Published online 8 May 2018 